specialists of art profile]. Materialy Vseukrainskoi naukovo-praktychnoi internet-konferentsii "Aktualni pytannia suchasnoi nauky”: Zb. nauk. Prats Proceedings of Ukrainian scientific-practical Internet conference "Actual questions of modern science": Coll. Of Scient. works. (pp. 125-130). Berezhany, Issue. 1. [in Ukrainian].

4. Kolisnyk-Humeniuk, Yu. (2016). Teoretychni ta metodychni zasady profesiino-pedahohichnoi pidhotovky vykladachiv profesiino-khudozhnikh dystsyplin u vyshchykh navchalnykh zakladakh [Theoretical and methodological foundations of professional and pedagogical training of teachers of professional and artistic disciplines in higher educational establishments]. Youth and market. No. 7, pp. 19-27. [in Ukrainian].

5. Rogov, Ye.I. (2012). Nastolnaya kniga prakticheskogo psikhljga v 2 ch. Chast' 2. Rabota psikhologa so vzroslymi. Korrektsionniye priyemy $i$ uprazhneniya: prakticheskoye posobiye [Handbook of the Practical Psychologist in 2 parts. Part 2. The work of a psychologist with adults. Corrective techniques and exercises: practical guide]. Moscow, 507 p. [in Russian].

Стаття надійшла до редакції 02.09.2019

УДК $378: 364.48$

DOI:

Юлія Грач, кандидат педагогічних наук, доиент кафедри соиіальної роботи і соціальної педагогіки Хмельницького національного університету

\title{
ДЕЯКІ АСПЕКТИ ПРОФЕСІЙНОЇ КОМПЕТЕНТНОСТІ НА РІВНІ ВИВЧЕННЯ НАВЧАЛЬНОЇ ДИСЦИПЛІНИ “СВІТОВІ МОДЕЛІ ТА СТАНДАРТИ ПІДГОТОВКИ ФАХІВЦІВ СОЦІАЛЬНОЇ СФЕРИ"
}

У статті висвітлюються проблеми компетентнісного підходу в системі вищої освіти. Автор проводить аналіз професійних компетенцій на рівні вивчення навчальної дисиипліни "Світові моделі та стандарти підготовки фахівців соціальної сфери". Автор аналізуе зміст понять “компетентності" та “компетениії". Проводиться аналіз особистої, соціальної та навчальної компетентності у контексті Рамкової програми оновлених ключових компетентностей для навчання протягом життя. Автор проводить аналіз змісту дефініцій “компетентність” та “компетенція” у науково-практичному ракурсі. Дається характеристика поняття "науково-дослідницької компетентності".

Ключові слова: компетентність; компетенція; особиста компетентність; соціальна компетентність; навчальна компетентність.

Jim. 5.

Juliya Hrach, Ph.D.(Pedagogy), Associate Professor of the Social Work and Social Pedagogy Department Khmelnytskiy National University

\section{ACTIVITIES RELATED TO PROFESSIONAL COMPETENCE ON THE BASIS OF THE INITIAL PRINCIPLE OF "SOCIAL MODELS AND STANDARDS OF PREPARATION OF SOCIAL SPHERE SPESIALISTS"}

The article highlights the problems of the competence approach in the higher education system. The author analyzes the conceptual issues of studying the peculiarities of training specialists in the social sphere in different countries of the world in the framework of studying the masters specialty "Social work" of the discipline "World models and standards of specialists in the social sphere training". The article defines the purpose and objectives of the discipline "World models and standards of specialists in the social sphere training". The author analyzes the content of the concept "competence". The author focuses on integrational changes in education in a global context. The article analyzes competences and competences in accordance with the Framework Program for Updated Key Competences for Lifelong Learning, established by the European Parliament and the Council of the European Union on 17 January 2018. The author analyzes personal, social and educational competences, characterizes basic knowledge, skills and attitudes in accordance with this competence. The article analyzes the content of the definition "competence" in the scientific and practical perspective. The article describes the concept "scientific research competence". The author defines the content of professional competences on the basis of the discipline "World models and standards of specialists in the social sphere training". The article focuses on the integration of theoretical knowledge and practical experience of training social specialists in the process of developing methodological recommendations for the implementation of such experience in the system of training of relevant specialists in 
ДЕЯКІ АСПЕКТИПРОФЕСІЙНОӤ КОМПЕТЕНТНОСТІНАРІВНІ ВИВЧЕННЯНАВЧАЛЬНОӦ ДИСЦИПЛІНИ “СВІТОВІ МОДЕЛІ ТАСТАНДАРТИПІДГОТОВКИ ФАХІВЦІВ СОЦАЛЬНОӤ СФЕРИ”

Ukraine as a key competence of the discipline "World models and standards of specialists in the social sphere training". The author recommends to take into account the conceptual principles of formation of professional competencies of social sphere specialists at the level of study of the discipline "World models and standards of specialists in the social sphere training" provided that they are integral characteristics.

Keywords: competence; competency; individual competence; social competence; initial competence.

П остановка й обгрунтування актуальності проблеми. Відповідно до вимог модернізації, якісного перетворення системи вищої освіти України актуальності набуває вивчення й впровадження світового досвіду організації соціальної освіти. Опора на зарубіжний досвід підготовки фахівців соціальної сфери є складовою академічного використання найбільш раціональних засад вищої школи зарубіжжя при збереженні кращих надбань власної теорії та практики щодо професійної підготовки зазначених фахівців.

Аналіз основних досліджень і публікацій. Проблеми професійної компетентності розглядаються у дослідженнях таких науковців як Б.І. Мокін, В.М. Мізерний, О.М. Мензул. Аналіз понять “компетенція”, “компетентність”, "науково-дослідницька компетентність" дається у працях М.С. Голованя, А.В. Хуторського, Д.С. Мацько та ін.

Метою статті $\epsilon$ розкриття змістових характеристик професійних компетенцій на рівні вивченні навчальної дисципліни "Світові моделі та стандарти підготовки фахівців соціальної сфери”.

Виклад основного матеріалу. Представлення концептуальних питань вивчення особливостей підготовки фахівців соціальної сфери у різних країнах світу академічно обгрунтовано у рамках вивчення магістрами спеціальності "Соціальна робота" навчальної дисципліни "Світові моделі та стандарти підготовки фахівців соціальної сфери”.

Метою дисципліни "Світові моделі та стандарти підготовки фахівця соціальної сфери” $\epsilon$ оволодіння магістрами знань, вмінь та компетенцій зарубіжного досвіду моделей та стандартів підготовки фахівців соціальної сфери, необхідних для конструктивної організації соціальної роботи з різними категоріями населення.

Під час вивчення навчальної дисципліни акцентується увага на особливостях професійної підготовки соціальних працівників у системі вищої освіти різних країн світу.

Завдання дисципліни "Світові моделі та стандарти підготовки фахівців соціальної сфери” полягають не тільки в представлені концептуальних питань вивчення особливостей підготовки фахівців соціальної роботи, але й допомагають студентам зрозуміти та розкрити нові динамічні можливості, які притаманні сучасному розвитку соціальної роботи зарубежем, розглянути нові підходи та моделі взаємозв'язку суб’'єктів та об'єктів соціальної роботи, позитивно вплинутина формуванняпрофесійноїлогікитакультури в умовах становлення фахівця соціальної сфери.

Актуалізація проблеми компетентнісного підходу в системі вищої освіти для України $е$ результатом ії приєднання до Болонського процесу. Протягом останніх років увага науковців зосереджується на питаннях модернізації усіх рівнів вищої освіти. Поняття “компетентності” та “компетенції” використовуються, як правило, для характеристики інтегрованого результату освітнього процесу, коли дослідниками фіксується недостатність тріади “знання-уміння-навички” [2] Якість вищої освіти України на сучасному етапі їі розвитку зумовлюється інтеграційними змінами освіти у світовому контексті. Європейський парламент і Рада Європейського Союзу 17 січня 2018 року схвалили Рамкову програму оновлених ключових компетентностей для навчання протягом життя [5]. У мінливому і тісно взаємопов'язаному світі кожна людина потребує широкого спектра навичок і компетенцій, які вона має постійно розвивати протягом усього життя. Основні компетенції, визначені в Рамковій програмі, спрямовані на створення засад для досягнення більш рівноправних і більш демократичних суспільств. Вони відповідають необхідності забезпечення всебічного та сталого розвитку, соціальної єдності та подальшого розвитку демократичної культури.

Особиста, соціальна та навчальна компетентність - це здатність усвідомлювати внутрішні стани, ефективно управляти часом та інформацією, конструктивно працювати 3 іншими людьми, залишатися стійкими і керувати власним навчанням та кар'єрою. Включає здатність справлятися з невизначеністю та складністю, учитися вчитися, підтримувати фізичне та емоційне благополуччя, співпереживати і конструктивно вирішувати конфлікти. Основні знання, вміння, навички та ставлення, пов'язані 3 цією компетенцією:

- особиста, соціальна та навчальна компетенція передбачає знання компонентів здоров'я розуму, тіла і способу життя;

- особиста компетентність передбачає уміння бути стійкими і здатними впоратися 3 невизначеністю та стресом; 
ДЕЯКІ АСПЕКТИПРОФЕСІЙНОӤ КОМПЕТЕНТНОСТІНА РІВНІ ВИВЧЕННЯНАВЧАЛЬНОӤ ДИСЦИПЛІНИ “СВІТОВІ МОДЕЛІ ТА СТАНДАРТИПІГОТОВКИ ФАХІВЦІВ СОЦІАЛЬНОӤ СФЕРИ”

- особистісні навички включають здатність виявляти свої можливості, концентруватися, справлятися зі складністю, критично аналізувати ситуації та приймати рішення;

- для успішних міжособистісних відносин та соціальної участі важливо розуміти кодекси поведінки та правила комунікації, прийнятні в різних суспільствах та середовищах;

- соціально важливим $є$ вміння конструктивно спілкуватися в різних середовищах, співпрацювати в командах та вести переговори. Воно передбачає толерантність, висловлення своєї та розуміння точок зору інших людей, а також здатність формувати і підтримувати упевненість і співчуття;

- навчальна компетентність включає знання стилів сприйняття і стратегій навчання, своїх здатностей і потреб розвитку. Важливо знати різноманітні способи розвитку своїх здатностей через доступні засоби освіти, які підтримують базове навчання, професійну підготовку та можливості кар'єрного зростання;

- навчальна компетентність передбачає здатність навчатися та працювати і спільно, і автономно, організувати та наполегливо здійснювати навчання, оцінювати прогрес і результати навчання. Важливим $є$ вміння шукати підтримки, коли це доречно, ефективно керувати кар'єрою та соціальними взаємодіями.

Особиста, соціальна і навчальна компетентність базується на позитивному ставленні до особистого, соціального та фізичного благополуччя та навчання протягом усього життя. Вона включає позитивне ставлення до співпраці, повагу до інших, наполегливість та цілісність, готовність до подолання упереджень та пошуку компромісів. Важливими є вміння визначати і ставити цілі, мотивувати себе, розвивати стійкість та впевненість, продовжувати навчатися протягом усього життя, аналізувати i вирішувати проблеми. Це підтримує і процес навчання, і здатність індивідуума долати перешкоди [5].

Для нашого дослідження доречним $\epsilon$ розглядати поняття “компетенції”, виходячи 3 тлумачення дефініції “компетентність”.

Компетенція є нормативною, ідеальною метою освітнього процесу, що моделює якості випускника, а компетентність - його результатом, рівнем прояву (сформованості). Поняття “компетенція” пов'язане із змістом сфери діяльності, а “компетентність" - з особистістю, із здатністю особи ефективно діяти у стандартних і нестандартних ситуаціях. Компетентність виявляється в успішно реалізованій у діяльності компетенції і включає особисте ставлення до предмету і продукту діяльності. У компетентності поєднуються об'єктивно визначені нормативними документами система знань, умінь і навичок, а також особистісна складова - інтереси, прагнення, ціннісні орієнтації, мотиви самореалізації індивіда $[3,52]$. Компетентність - динамічна комбінація знань, вмінь і практичних навичок, способів мислення, професійних, світоглядних i громадянських якостей, морально-етичних цінностей, яка визначає здатність особи успішно здійснювати професійну та подальшу навчальну діяльність і є результатом навчання на певному рівні вищої освіти $[1,11]$.

У нашому дослідженні ми розглядаємо формування професійних компетенцій на II рівні вищої освіти, магістерському. Це актуалізує необхідність аналізу змісту дефініцій “компетентність" та “компетенція" у науковопрактичному ракурсі. У цьому контексті варто охарактеризувати поняття “науково-дослідницької компетентності".

В класифікації А.В. Хуторського дослідницька компетентність розглядається як складова частина пізнавальної компетентності, яка включає “елементи методологічної, надпредметної, логічної діяльності, способи організації цілепокладання, планування, аналізу, рефлексіі”, вона слугує компонентом компетентності особистісного самовдосконалення, спрямованого на освоєння способів інтелектуального й духовного розвитку [4, 55 - 61].

У контексті нашого дослідження варто охарактеризувати зміст професійних компетенцій на рівні вивчення навчальної дисципліни “Світові моделі та стандарти підготовки фахівців соціальної сфери":

1) здійснювати пошук, аналіз і синтез інформації з різних джерел для встановлення причинно-наслідкових зв'язків між соціальними новаціями у зарубіжній системі підготовки фахівців соціальної сфери та практичними можливостями впровадження такого досвіду в системі соціальної освіти України;

2) формулювати власні обгрунтовані судження на основі аналізу світових моделей та стандартів підготовки фахівців соціальної сфери;

3) аналізувати закономірності становлення професії фахівця соціальної сфери у різних країнах світу;

4) теоретично аргументувати особливості вищої освіти зарубіжних країн з питань підготовки фахівців соціальної сфери;

5) аналізувати стан підготовки фахівців соціальної сфери в різних країнах світу; 


\section{ДЕЯКІ АСПЕКТИПРОФЕСЙНОӦ КОМПЕТЕНТНОСТІНА РІВНІ ВИВЧЕННЯ НАВЧАЛЬНОӤ ДИСЦИПЛІНИ “СВІТОВІ МОДЕЛІ ТАСТАНДАРТИПІДОТОВКИ ФАХІВЦІВ СОЩАЛЬНОӤ СФЕРИ”}

6) інтегрувати теоретичні знання та практичний досвід підготовки фахівців соціальної сфери у процесі розробки методичних рекомендацій щодо впровадження такого досвіду у систему підготовки відповідних фахівців в Україні;

7) виявляти та аналізувати проблеми підготовки фахівців соціальної сфери в різних країнах світу;

Охарактеризуємо детальніше кожну із зазначених компетенцій.

Щодо першої, загальної компетенції варто зауважити, що причинно-наслідкові зв'язки між соціальними новаціями у зарубіжній системі підготовки фахівців соціальної сфери та практичними можливостями впровадження такого досвіду в системі соціальної освіти України $\epsilon$ тим логічним стрижнем, навколо якого i уможливлюється якісне перетворення сучасної соціальної освіти України у інноваційне середовище, в якому сучасні студенти набуватимуть ключових компетентностей, необхідних для успішного здійснення професійної діяльності.

По-друге, формулювання власних обгрунтованих суджень на основі аналізу світових моделей та стандартів підготовки фахівців соціальної сфери $\epsilon$ запорукою формування професійної майстерності. Це умова формування професійної свідомості.

Аналіз закономірностей становлення професії фахівця соціальної сфери у різних країнах світу виступає чинником формування особистості фахівця соціальної сфери, $є$ результатом формування професійної логіки.

Розуміння особливостей та стану підготовки фахівців соціальної сфери зарубіжних країн $\epsilon$ необхідною умовою формування соціальнопрофесійної мобільності магістрів соціальної сфери.

Розробка магістрами методичних рекомендацій щодо впровадження зарубіжного досвіду підготовки фахівців соціальної сфери у систему підготовки відповідних фахівців в Україні, на нашу думку, $\epsilon$ умовою формування науководослідницьких компетенцій. Це дозволить фахівцям соціальної сфери виокремлювати актуальні проблеми у практиці соціальної роботи, проводити наукові дослідження з обраної проблематики та впроваджувати отримані результати в професійну діяльність 3 метою ii оптимізації. Вважаємо, що саме формування цієї компетенції уможливлює розвиток науковопрактичного мислення магістрів, сприяє якісним змінам у професійному становленні особистості.
Поряд $з$ цим, вміння виявляти та аналізувати проблеми підготовки фахівців соціальної сфери в різних країнах світу дозволяє магістрам зрозуміти сутність, аспекти динаміки, мобільність соціально-освітніх процесів, які, безсумнівно, мають місце у просторі сучасної соціальної сфери та можуть як конструктивно, так і деструктивно впливати на якість соціального життя.

Висновки. Аналіз професійних компетенцій у контексті вивчення навчальної дисципліни “Світові моделі та стандарти підготовки фахівців соціальної сфери" дозволяє акцентувати увагу на важливості їх формування у комплексі 3 особистісним ростом та становленням як відповідного фахівця. Розвиток особистісних та професійно важливих якостей фахівців соціальної сфери є обов'язковою умовою професійного становлення 3 однієї сторони та якісним результатом формування відповідних компетенцій 3 іншої. Саме професійна свідомість як результат дуалістичного підходу до розуміння професійного становлення фахівця соціальної сфери є умовою конструктивної модернізації сучасної соціальної освіти в Україні. Сучасна система вищої освіти України активно впроваджує досвід світових моделей підготовки фахівців, використовує інноваційні форми та методи організації навчально-виховного процесу, забезпечуючи цим створення інноваційного, якісно нового, сучасного освітнього простору.

Рекомендації. Важливо зазначити, що концептуальні засади формування професійних компетенцій фахівців соціальної сфери на рівні вивчення навчальної дисципліни “Світові моделі та стандарти підготовки фахівців соціальної сфери" варто враховувати за умови їх інтегральної характеристики. Це зумовлено динамізмом сучасної соціальної сфери з однієї сторони, та мобільністю світових освітніх систем 3 іншої. Саме інтегральна характеристика компетентностей у контексті моделей підготовки фахівців соціальної сфери різних країн світу визначає можливості їх конструктивного впровадження в систему вищої соціальної освіти України.

Перспективи подальших досліджень. Напрями подальших досліджень окресленої проблеми полягають у розробці соціальноорієнтованих інноваційних форм та методів організації навчально-виховного процесу, створенні навчально-дослідних умов формування професійно важливих компетенцій у процесі поєднання теоретичної підготовки та соціокультурної діяльності майбутніх фахівців соціальної сфери. 
ДЕЯКІ АСПЕКТИ ПРОФЕСІЙНОЇ КОМПЕТЕНТНОСТІНА РІВНІ ВИВЧЕННЯ НАВЧАЛЬНОӤ ДИСЦИПЛІНИ “СВІТОВІ МОДЕЛІ ТА СТАНДАРТИПДГОТОВКИ ФАХІВЦІВ СОЦАЛЬНОӤ СФЕРИ”

ЛIТЕРАТУРА

1. Бегняк В.І., Красильникова Г.В. Система внутрішнього забезпечення якості освітньої діяльності : зб. нормативних документів. Хмельницький, 2015. 445 с.

2. Воронкова В.Г. Сучасні шляхи втілення Болонської системи у ВНЗ України. Матеріали науково-практичного семінару “Кредитномодульна система підготовки фахівців у контексті Болонської декларації”. Львів, 2003.

3. Головань М.С. Компетентнісний підхід як методологічна основа вищої професійної освіти. Психологія: реальність і перспективи : збірник наукових праць Рівненського державного гуманітарного університету. Випуск 1. Рівне, 2011. C. 53-59.

4. Хуторской А.В. Ключевые компетенции как компонент личностно-ориентированной парадигмы образования. Народное образование. 2003. №2. C. 55-61.

5. ANNEX to the Proposal for a Council Recommendation on Key Competences for Lifelong Learning. Available at: https://ec.europa.eu/education/ sites/education/files/annex-recommendation-keycompetences-lifelong-learning.pdf.

\section{REFERENCES}

1. Begnyak, V.I. (2015). Systema vnutrishnoho zabezpechennia yakosti osvitnoi diialnosti : zb. normatyvnykh dokumentiv [Internal quality assurance system of educational activity: a collection of regulatory documents]. Khmelnitsky, 445 p. [in Ukrainian].

2. Voronkova, V.G. (2003). Suchasni shliakhy vtilennia Bolonskoi systemy u VNZ Ukrainy [Modern ways of implementation of the Bologna system in Ukrainian universities]. Proceedings of the ScientificPractical seminar "Credit-module system of training of specialists in the context of the Bologna Declaration”. Lviv. [in Ukrainian].

3. Golovan, M.S. (2011). Kompetentnisnyi pidkhid yak metodolohichna osnova vyshchoi profesiinoi osvity [Competence approach as a methodological basis of higher professional education]. Psychology: Reality and Perspectives: Collection of Scientific Papers of Rivne State Humanities University. Rivne, pp.53-59. [in Ukrainian].

4. Xutorskoj A.V. (2003). Klyuchevye kompetentsii kak komponent lichnostno-orientirovannoy paradigmy obrazovaniya [Key competencies as a component of the personality-oriented education paradigm]. No.2. Moscow, pp. 55-61. [in Russian].

5. ANNEX to the Proposal for a Council Recommendation on Key Competences for Lifelong Learning (2018). Available at: https://ec.europa.eu/ education/sites/education/files/annexrecommendation-key-competences-lifelonglearning.pdf. [in English].

Стаття надійшла до редакції 20.09.2019

\section{G58080.2058080} робитu”.

"ТІеперішній час нічим не гірший за будь-який інший, яжщо ти знаєщ, що з ним

$$
\begin{array}{r}
\text { Ральб Емерсон } \\
\text { американський білософ, письменник }
\end{array}
$$

“Фавай настанови лише тим, хто шуқає знання, визнавши своє невізластво. Dопомагай лише тому, хто не вміє чітко висловлювати свої найпотаємніші думки. Навчай лише того, хто здатен, дізнавшись про один қут квадрата, уявити собі решту mpu”.

Конфучиiü

давньокитайський білософб

"Розвинені почуття, висока емочійна қультура - це, образно қажучи, абсолютний музичний слухморальної вихованності".

Василь Сухомлинський украӥнський педагог, публіиист, письменник, поет

\section{G58080}

